University for Business and Technology in Kosovo

UBT Knowledge Center

UBT International Conference

2015 UBT International Conference

Nov 7th, 9:00 AM - 5:00 PM

\title{
Tourism development post global financial crisis: Case of Albania
}

Arjan Tushaj

University of Tirana, arjantushaj@hotmail.com

Rakela Thano

University of Tirana, mrkels@yahoo.com

Follow this and additional works at: https://knowledgecenter.ubt-uni.net/conference

Part of the Business Commons

\section{Recommended Citation}

Tushaj, Arjan and Thano, Rakela, "Tourism development post global financial crisis: Case of Albania" (2015). UBT International Conference. 22.

https://knowledgecenter.ubt-uni.net/conference/2015/all-events/22

This Event is brought to you for free and open access by the Publication and Journals at UBT Knowledge Center. It has been accepted for inclusion in UBT International Conference by an authorized administrator of UBT Knowledge Center. For more information, please contact knowledge.center@ubt-uni.net. 


\title{
Tourism development post global financial crisis: Case of Albania
}

\author{
Arjan Tushaj ${ }^{1}$, Rakela Thano $^{2}$ \\ ${ }^{1,2}$ Department of Economics, Faculty of Business Administration and Economics, \\ University of Tirana, \\ arjantushaj@hotmail.com ${ }^{1}$, mrkels@yahoo.com ${ }^{2}$
}

\begin{abstract}
Tourism is the elastic sector and capable of demonstrating the significant capacity past the crisis occurrence despite it is more appreciable in the short run. The global financial crisis during $2008-2009$ passed likewise the adverse external shock to developing countries and we faced to the consequences of it. It had the significant impact on the tourism sector. Empirical results demonstrated that tourist revenues tend to be more affected than cash tourist during the time of crisis. Impact of the crisis on the tourism sector associated with the different effects in diverse countries. The crisis around the world brought to Albania the highest number of tourists, but tourism receipts per tourist were lower compared to other years. The goal of this paper is to analyze the impacts of post global economic crisis on the tourism sector according to Albania and around the diverse world regions. The paper investigated the indicators of tourism sector linking to Albania and global regions through the comparative static and dynamic analysis during 2009 - 2014. We concluded that the impact of crisis in the tourism sector and its renovation were altering to dissimilar countries. The global tourism renovated during 2012, meanwhile the Albanian tourism sector was renovating during 2014.
\end{abstract}

Keywords: Tourism sector, global financial crisis, tourism indicators

\section{Introduction}

Tourism is one of the most dynamic sectors to contribute in the absolute and relative terms according to the global economic growth. The tourism has significant multiple effects on other sectors of the economy and contributes to the comprehensive economic development of countries because it is the leading activity in several countries. The growth of tourism the latest decade has amplified the impact directly related to the socio-economic development due to it contributes appreciably to the living standards of developed tourist areas, and so on the welfare of society.

Business volume of tourism on the global dimension can exceed the volume of oil exports, food and cars and remaining the main source of revenues according to several developing countries.

Global tourism faces the most important challenges early on 21 st century related to the sustainable and balanced development, the elimination of disparities according to the wealth and opportunities, but also the proper distribution and management of existing natural resources.

The crisis of 2008 affected the several countries and the Mediterranean region was no exception. Actually the countries of the Mediterranean region appreciate the resources and their potential related to the future of the tourism sector after the global economy seems to be recovering from the economic crisis. They tried to find the ways to protect or restore their position like the leading international tourist destinations.

Aydin (2013) highlighted that the effects of the global economic crisis on the primary economic indicators diverged amongst the developing and developed countries. Meanwhile Henderson (2007) investigated that the impact of the economic crisis would be the accelerant in the development of tourism in small countries, since the tourism has the significant contribution to the local economy of them. Particularly the economic crisis cut the demand for tourism due to the reducing the disposable income. The paper is organized as follows. The following section presents an introduction to the tourism behavior and its impacts during the crisis. Section 2 provides a review of the relevant 
literature. Section 3 and 4 present the global, European and Albanian tourism post the financial crisis. And finally Section 5 presents the concluding remarks.

\section{Literature review}

The global financial crisis of 2008 had the significant impact on the tourism sector. Various authors investigated the impact and consequences of it relying on the theoretical and empirical background. Sian et al. (2009) classified into two groups the threats of internal and external economic crisis according to the tourism industry which they were: first group related to the external threats like recession, currency fluctuations and taxes, and the second group related to the internal threats like rising costs, declining revenue, decreasing profits.

Mazilu (2011) emphasized that the tourism in the world has practised the steady growth along numerous decades, but it suspended by the global financial crisis. The global crisis means the moment of uncertainty, but the endless possibilities. It is really that we are faced to the large deficits, the rising unemployment rate and the decreasing of the reliance in the market. This crisis carried on the continuous pressure according to tourists at the same time; particularly to the employees of the tourism industry and it threaten the current policies and practices.

Hapenciuc.et al (2009) highlighted that the developing markets are more vulnerable to crisis, but they adjust simply into the resent context relying on the flexible economic activities like the tourism industry. The persistence of global economic crisis, above all the fragility of the tourist market makes impossible to assess the evolution of the hospitality industry for the coming years.

Cohen (2012) demonstrated that the financial crisis of 2008 crisis and its impact on the tourism analyzed by the several authors related to their countries. They linked the occurrence of crisis to globalization trend.

Andrei (2010) analyzed the relationships between the number of tourists to access in the Romania and the accommodation capacity. The author emphasized that the strategy of Romania's development should be included the tourism development in order to enclose the sustainable development. Also the analysis of the crisis's impact in Europe and Romania was appreciating by Costea (2009) and Stănciulescu, and Micu (2009).

Petrevska (2012) investigated the effects of the global economic crisis on tourism in Macedonia and the consequences according to the comprehensive economic development. The analysis of author divided into two periods in order to provide the robust results related to the crisis's impacts. The first period referred to 2002-2007, the time before the global crisis and the second period referred to 20082010 related to the short-run results of the crisis. The results indicated that Macedonia likewise the most countries oriented to tourism had not excluded to the negative shocks.

Ritchie (2004) argued that the tourism enterprises were sensitive to the political, socio-economic and technological changes according to global circumstances thus they required the effective treatment by tourism managers.

\section{A slight view around global and European tourism post global financial crisis}

The economic slowdown of 2008 marked the largest economic crisis after World War II. The large economies of the world had the economic declining, the consumers and businesses reduced their expenditure rapidly and tourist industry was among the main branches of the economies associated with the prompt decreasing. The tourist arrivals were reduced by $4 \%$, total overnights and the expenditures reduced by $7 \%$ and $9 \%$ respectively associating with the large loss in the tourist industry (OECD, 2010). The economic crises caused the long - run recessions and they could lead to the unexpected decline to the tourist demand in the diverse important tourist markets according to the destination (Beirman, 2003).

It confirmed that the war and crisis occurrence linked to the decreasing rate of tourism development. The tourism improved rapidly due to the short duration of them. Miller and Ritchie (2003) argued that the nature of the tourism industry forced the industry should be better prepared to deal with crises, 
disasters and fluctuations, while Henderson and $\mathrm{Ng}$ (2004) point out the common business operations could restore with the abrupt vehicles.

Three aspects should be emphasized according to the OECD (2010) that they exacerbated the recession:

$\checkmark \quad$ The reduction of business travels distinguished to entertainment travel due to the businesses are making efforts to reduce their costs, but also to take advantages of technology development (Freitag and Pyka (2011))

$\checkmark$ Reducing the demand for hotels in contrast to other types of tourist accommodation

$\checkmark$ Reducing the demand for air transport in contrast to other types of transport

The tourism sector recognized like the major source of economic development and world employment during the economic instability. The financial crisis of 2007-2008 demonstrated approximately the global recession (Tribe, 2011). The year of 2007 came out as the fourth consecutive year of robust growth according to the global tourist industry, while 2008 affected considerably the global tourism by the global economic crisis and it overturn until the first half of 2009. Meanwhile the international tourism grew up robustly during 2010. According to UNWTO (2011) the international tourism receipts increased by almost 7\% reaching 935 million euro and the enormous destinations in the worldwide showed the positive figures sufficient to offset the losses during the last two years. However the upturn has been with the diverse haste and promptly came to the emerging economies denoting $8 \%$, while the developed countries associated with the growth by $5 \%$. Europe had the lowest tempo with $3 \%$ due to the economic instability.

The tourist industry continued to expand during 2011. Tourism continued the increasing trend and exceeded 1 billion tourists moving around the world at the first time during 2012. Tourism demonstrated the significant role in the global economies and the counterbalance against the global instability. It was the principal feature of tourism that it was improved within the short time. According to the world organization of tourism emphasized that the world tourism receipts reached to 837 billion euro during 2012 denoting the growth by 4\% compare to 2011 (UNWTO (2013)). It should be noted that USA had the highest receipts by increasing $7 \%$ along to 2012 , while Europe had the receipts by increasing to $2 \%$. Europe achieved 356 billion dollars of tourist receipts which they comprised $43 \%$ of the world tourist receipts. European countries were the most required destinations during 2012 despite of the political and economic instability. The number of tourists visiting Europe along 2012 increased by $3.4 \%$ continuing the positive trend compare to the increasing by $6.4 \%$ in 2011. Eastern European destinations had the highest increase than Western European destinations. Meanwhile the European Mediterranean destinations had an increase of 2.2\% (UNWTO (2013)).

Despite numerous challenges faced international tourism in 2014, the international tourism continued to move forward along 2014 despite the numerous challenges. The number of international tourists travelling around the world grew by $4.4 \%$ and reaching over 1.1 billion tourists in the end of 2014 . Tourism continued to be the principal promoter of the global economic improvement. International tourism revenues amounted to 1245 milliard \$ around the worldwide and corresponding to an increase of $3.7 \%$ in real terms compared to 2013. The continued progress and expansion of tourism characterized likewise the effective solution related to various countries in the world due to the contribution according to the inducing of employment, reducing of poverty, the protection of the environment and multicultural peace.

\section{Albanian tourism post global financial crisis}

The macroeconomic circumstances in Albania associated with the rapid non-inflationary economic growth in contrast to most other transitional economies before the global financial crisis. Albania has continued to pursue the policy of the steady economic development demonstrating by the macroeconomic data along these years. Albania's economy resisted to the shocks waves from the global financial crisis and grew up approximately 6\% during 2008 and demonstrated the positive growth along 2009 as well. Despite the severe economic downturns and confident shocks to the various countries in Europe and other advanced economies, furthermore the decreasing of Albanian exports and remittances, the economic growth rate in Albanian denoted 3\% during 2009 (Bank of Albania (2008), (2009)).

The current financial crisis according to the developed countries was spreading likewise the adverse external shock to several developing countries. The sluggish growth rate related to the developed 
countries associated with decreasing of exports, remittances and the external financings in markets of developing countries and transmitted likewise the economic crisis.

We concluded that the Albanian economy affected with the limited impact by the global financial crisis due to the low integration on the global markets, the appropriate economic policies and the lack of financial markets. These reasons deflected the financial crisis in Albania, but not the economic crisis.

Tushaj and Thano (2014) highlighted that the increasing of revenues derived by tourism affected positively to the economic growth which it sustained by the rising tourism contribution to GDP in Albania. Empirical results demonstrated that the Albanian economy could affect to the economic growth through the consolidation of tourism industry likewise the potential determinants. Results indicated that the investments related to physic and human capital, foreign direct investment and household consumption affected positively the economic growth. These results demonstrated their determined potential like the productive factors to economic growth according to the theoretical and empirical literature.

The tourism sector in Albania is one of the dynamic sectors of economy with the significant contribution to GDP, employment, investments and exports. The contribution of tourism in Albania according to these indicators was higher than the average value of contribution in Europe during 2014. The total contribution of tourism according to GDP in Albania was $21 \%$ along the latest year, also the contribution to total employment was $19.2 \%$ and to exports was $30.4 \%$ referring to the figure 1 .

Figure 1 The contribution of the tourism sector in Albania and Europe during 2014 (\%)

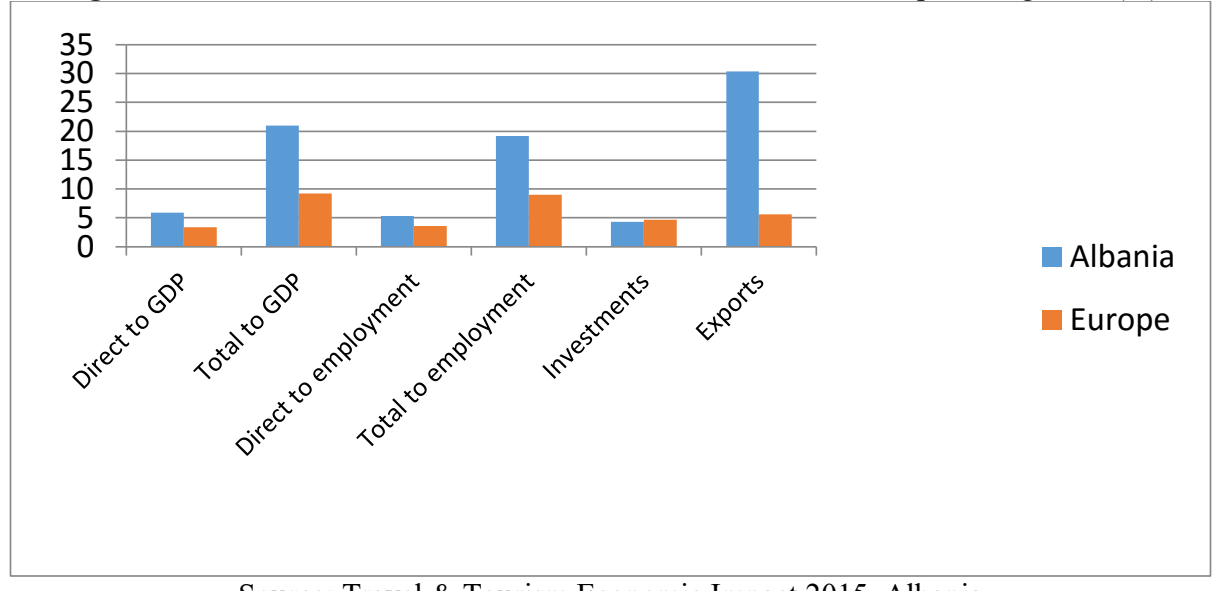

Source: Travel \& Tourism Economic Impact 2015, Albania

Albanian tourism ranked at 61 st position from 200 world destinations related to the tourist arrivals at the global classification during 2012. It represented $0.33 \%$ of the world tourist arrivals and meant that Albanian tourism is the competitive sector of national economy compare to global standard (UNWTO (2013)). Likewise the principal component of development in numerous countries and despite the economic potency and its flexibility, the tourism is the most susceptible to the diverse internal and external shocks such as: the economic downturn, the natural disasters, the epidemic diseases and the international conflicts. Although the consequences of crisis may undermine all the tourist destinations, meanwhile the duration of renovation can be altered according to each destination.

The small countries likewise Albania relied usually on the foreign investment and the global tourist system which they have purposed to control the decision-making according to the development of tourism in the hospitable countries. This relationship induced the sensitivity related to the global tensions and crisis and presented the challenges in support of the local natural sustainability of natural resources, socio-cultural sustainability and economic environment. Tensions and crises are part of the globalization processes which they reorganized the global economic systems and global political and cultural system (Stiglitz, (2003)). The globalization has intensified the competition amongst the destinations to attract the tourist affluxes (Meethan, (2001)). The recent global economic crisis had the major impact on the various destinations in the worldwide. It has caused the severe problems to the long-run development of tourism in the case of small countries due to their furtherance on tourism. 
Carlsen and Butler (2011) investigated that the tourism's development threatened sometimes the sustainable management of limited resources with socio-cultural nature, even if the tourism was considerably to the economic growth in small countries.

$>$ International tourist arrivals post crisis

We can say that the global financial crisis has not affected the tourism industry in Albania if we are referring to the number of international tourists visiting Albania. We might say that Albania has benefited from the crisis according to the number of tourists referring to the figure 2, even taking advantage of tourists spending their holidays in the Mediterranean due to the political instability. The number of international tourists to Albania has increased 159\% during 2014 compared with 2008.

Figure 2 Number of international tourist arrived in Albania during 2007 - 2014

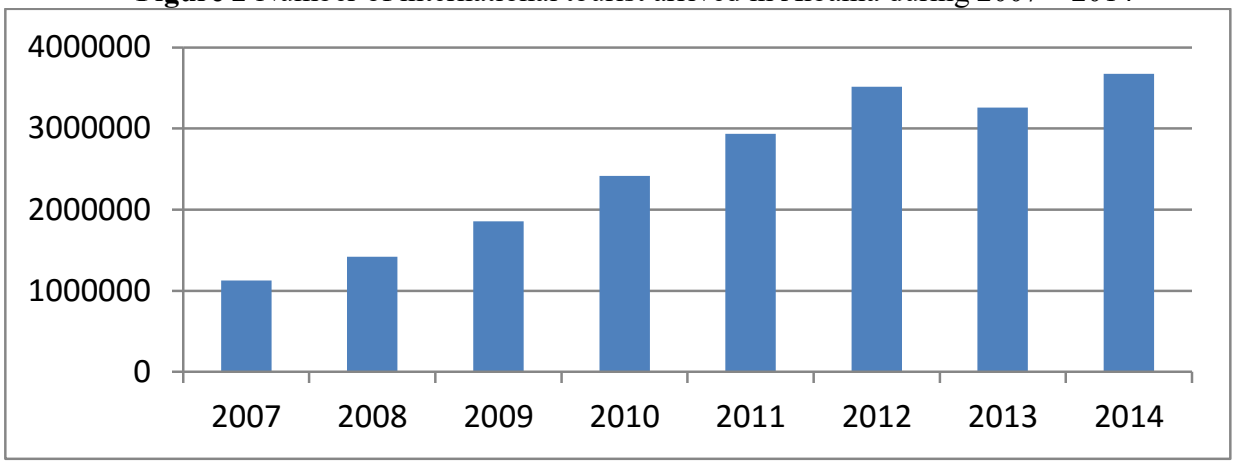

Source: INSTAT, 2015

\section{Tourist receipts post crisis}

Albania suffered the effects of crisis related to the tourist receipts which they were declining on behalf of successive years referring to the figure 3 after 2009 when the world tourism began to emerge from the crisis and the overnights showed the large declining after 2011 referring to the figure 4.

Antonelli (2011) emphasized that the world faced to the worst crisis since the Great Depression. The author identified the two waves of crisis: the first wave began in mid of 2007 and the second wave spread since 2009 which it has severely affected the real economy. Albanian tourist receipts were declining by $20.6 \%$ during 2013 compare to 2009 , while the overnights were declining by $36.8 \%$ during 2013 compared to 2009.

Figure 3 Albanian tourist receipts during 2007 - 2013 (US\$ million)

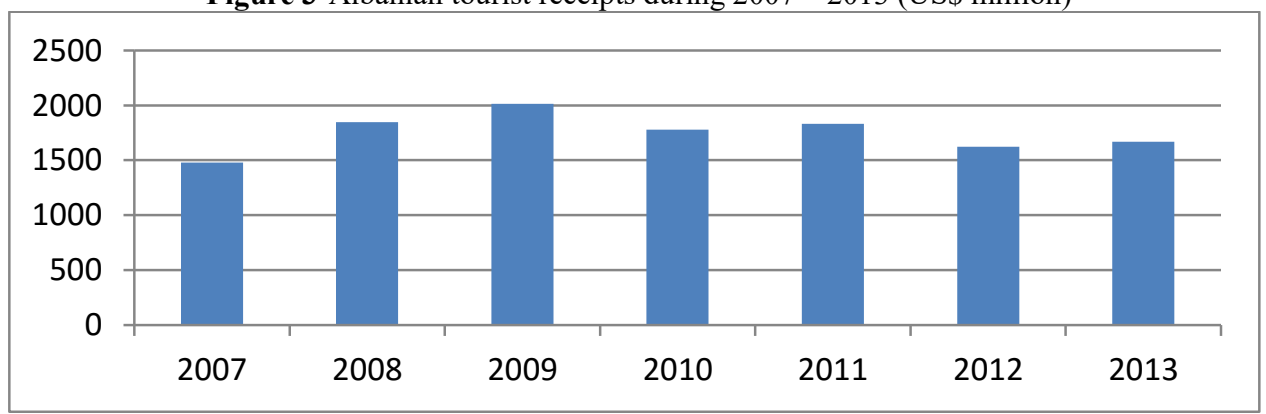

Source: The World Bank World Development Indicators, 2014 
Figure 4 Overnights of international tourists in Albania during 2007 - 2014 (in thousands)

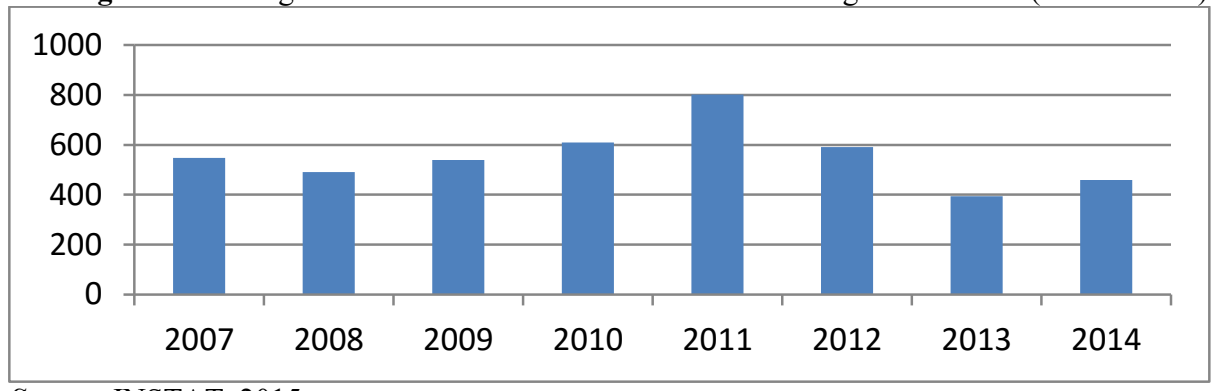

Source: INSTAT, 2015

$>$ Employment in tourism sector post crisis

The effects of crisis in the Albanian tourism were demonstrated to the employment. After 2009 the direct employment in tourism denoted the decreasing by $14 \%$ until the end of 2012, meanwhile it indicated the upward trend during 2013 referring to the figure 5. The high unemployment rate in the tourism sector remains the principal concern to policy makers despite of the plodding renewal in 2013 it remains too weak to offset the loss of jobs during 2010 related to post economic crisis.

Figure 5 Direct employments in Albanian tourism sector during 2009 - 2014 (in thousands)

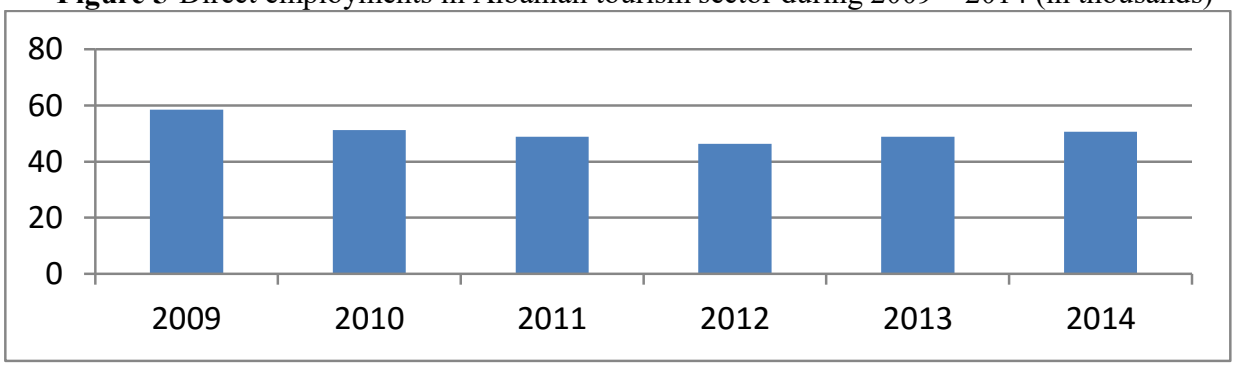

Source: Travel \& Tourism Economic Impact 2015, Albania

Reducing of tourists spending and overnights affected to the decreasing of total contribution of tourism according to the employment, thus reducing the employment in other branches of industries linking directly and indirectly with the tourism sector. Despite the upward trend related to the contribution of tourism to employment, it denoted the decreasing by $15.1 \%$ in 2014 compare to 2009 .

Figure 6 The total contribution of Albanian tourism in the total employment (in thousands)

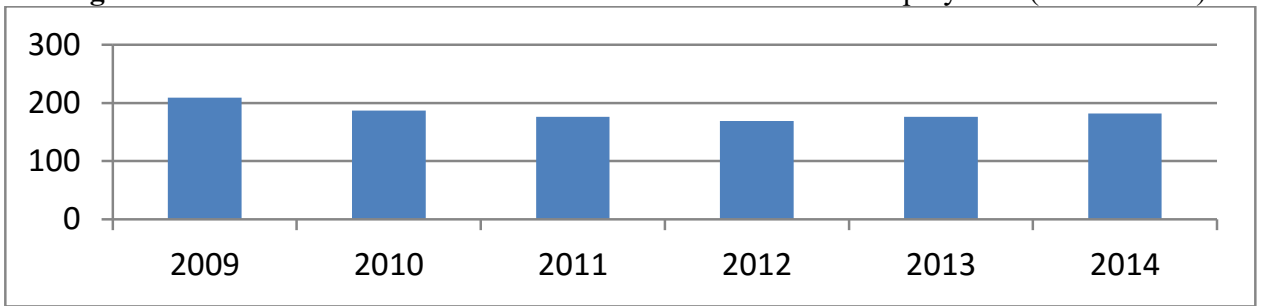

Source: Travel \& Tourism Economic Impact 2015, Albania

Since the economic crisis brought the new circumstances on the global tourism industry, the tourism industry was related robustly to the macroeconomic indicators like unemployment and public debt meaning the increasing taxes and reducing the purchasing power of consumers. Referring to these circumstances the internal tourism was the more sustainable than the international tourism, since the various families chose their national destinations (OECD (2010)).

Also the little bookings are made in the last minute, while the price of overnight is decreasing considerably. Packages of "all inclusive" are the most important due to the calculation of tourist 
spending; meanwhile they demonstrate the best ratio according to the price-performance (Freitag and Wedge (2011)).

$>$ The tourist investments post crisis

The tourism investments to the region have the important impact according to both tourism and the whole economy, because they promote the tourism development of country or region. Tourist investment characterized by instability conversely to the tourist consumption demonstrating the prompt and continuous inter-temporal fluctuations. Referring to the figure 7 showed that the tourist capital investments in Albania increased by 2\% during 2010. They associated with the decreasing in 2011 and continued the upward trend after that until 2014 when they attained the value of 2009 .

Figure 7 Capital investments according to tourism sector in Albania during 2009 - 2014 (ALL billion, nominal prices)

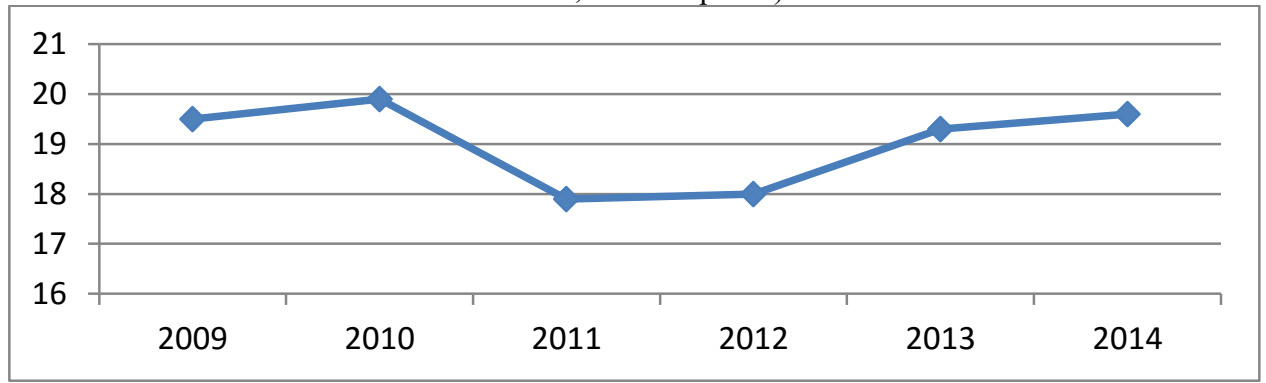

Source: Travel \& Tourism Economic Impact 2015, Albania

$>$ Exports of visitors post crisis

The international tourism contains the significant role in efforts to balance their balance of payments related to the various countries. Several developed and developing countries instigated to consider the tourism as the integral part of their economic growth because it provided the source of foreign currency. Exports contribute positively to economic growth easing the foreign exchange restrictions or increasing the efficiency through the enlarged competition. Lanfranchi, et al. (2014) emphasized that tourism was considering the main source of trade balance in most developed countries along many years. Over time the demand would be more diverse and would lead to search the new products and various supplies. Tourism's exports composed the largest share of exports in the services sector and the whole exports according to the countries considering the tourism likewise the foremost branch of services sector and their economy.

The tourist exports in Albanian declined robustly during 2012 likewise the others indicators of tourism. The decreasing demonstrated since 2010, meanwhile the world tourism began to make progress. The tourism's exports have declined by $9.5 \%$ during 2012 compare to 2009 referring to the figure 8 and increased by $0.5 \%$ during 2014 compare to 2009 indicating the upward trend of them.

Figure 8 Exports of visitors to tourism sector in Albania during 2009 - 2014 (ALL billion, nominal prices)

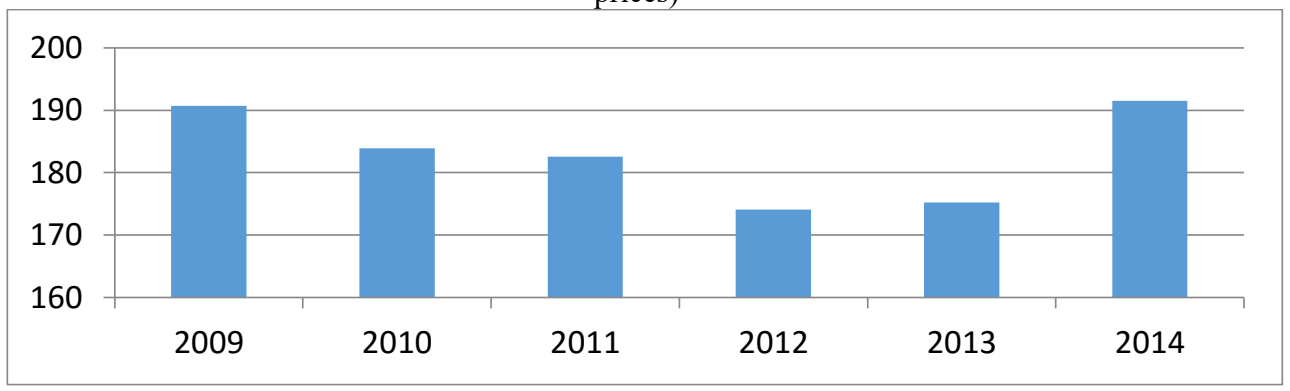

Source: Travel \& Tourism Economic Impact 2015, Albania 


\section{Concluding remarks}

The global financial crisis of 2008 transmitted likewise the adverse external shock to developing countries. It had the considerable impact on the tourism sector and associated with the diverse effects to various countries. The international tourism continued to move forward along 2014 and continued to be the principal promoter of the global economic improvement.

Albanian economy deflected to the global financial crisis due to the restricted integration on the global markets and the lack of financial markets. However it confronted to the economic crisis through the downward trend of growth rate and the declining of exports and remittances.

Empirical results highlighted that the increasing of revenues derived by tourism affected positively to the economic growth and could affect to it through the consolidation of tourism industry likewise the potential determinants. The tourism sector in Albania contributed significantly to GDP, employment, investments and exports during post crisis. Albania suffered the effects of crisis related to the tourist receipts, employment, tourism investment and tourist export which they demonstrated the diminishing ratio until 2012. Meanwhile the global financial crisis has not affected the number of international tourists visiting Albania which they showed the upward trend. Albanian tourism refined the determinant indicators and made the progress after 2012. Albanian tourism should be deflected the recession through providing the competitive services with quality and implementing the steady policy of tourism development.

\section{References}

1. Andrei, R. 2010. "International Affairs Analysis Correlation Between Accommodation in Function and Number of Turists Arriving in Romania during 2000-2008" Ovidius University Annals.Economic Sciences Series. Volume X, Issue 1.Year 2010.

2. Antonelli, G. 2011. "Global economic crisis and systemic failure". Economia Politica. Journal of Analytical and Institutional Economics, Vol. XXVIII, N. 3, pp: 403-434.

3. Aydin, S. 2013. "The Effects of Global Economic Crisis on Tourism. Mobilities in the Developed and the Developing Countries". International Journal of Business Tourism and Applied Sciences Vol. 1 No.2 July-December, 2013.

4. Bank of Albania, Annual Report: $2000-2014$.

5. Beirman, D. 2003. "Restoring Tourism Destinations in Crisis: A Strategic Marketing Approach". Allen\&Unwin: Crows Nest.

6. Carlsen, J. and Butler, R. 2011. "Introducing sustainable perspectives of island tourism". In Island Tourism: Sustainable Perspectives, Carlsen J, Butler R. (eds). CAB International: Osfordshire; 1-8.

7. Cohen, E. 2012. "Globalization, Global Crises and Tourism”. Tourism Recreation Research. Vol 37(2). 2012. Pp: 103-111.

8. Costea, R. I. 2009. "Tourism in the middle of the global crisis", Journal of Tourism - studies and research in tourism, no.7, Suceava University Press, pp:108-114.

9. Freitag, R. and Pyka, D. 2011. "Status Quo and Forecasting World and European Tourism”. In Conrady, P.and Buck, M.(eds.), Trends and Issues in Global Tourism 2011, Berlin: SpringerVerlag, pp: 3-17.

10. Hapenciuc. V.; Stanciu, P.; Condratov, I.; Nistoreanu, P. 2009. "Safe-Tourism in Crisis Situations, Appreciations in Romania's Case." Journal of Tourism- Studies and Research in Tourism. 2009. Volume 7, Issue 7.pp: 47-56.

11. Henderson, J.C. 2007. "Tourism Crises": Causes, Consequences \& Management. Elsevier Inc.: Oxford.

12. Henderson, J.C. and Ng, A. 2004. "Responding to Crisis: Severe Acute Respiratory Syndrome (Sars) and Hotels in Singapore". International Journal of Tourism Research 6(6). pp:411-419.

13. INSTAT. Instituti i Statistikës në Shqipëri. (http://www.instat.gov.al/al/home.aspx)

14. Lanfranchi, M.; Giannetto, C. and De Pascale, A. 2014. "Rural Tourism: A Kind of Sustainable Tourism in the Face of Global Economic Crisis" International Journal for Responsible Tourism , 2014. Vol. 3, No. 2.pp:15-28. 
15. Mazilu, M. 2011. “The Economic Crisis -A Constant Pressure on Tourism”. Review of Economics \& Finance Submitted on 21/June/2011 Article ID: 1923-7529-2011-05-43-14.

16. Meethan, K. 2001. "Tourism in Global Society": Place, Culture, Consumption. Palgrave: New York.

17. Miller, A. G. and Ritchie, B. W. 2003. "A farming crisis or a tourism disaster? An analysis of the foot and mouth disease in the UK". Current Issues in Tourism 6(2). pp: 150-171.

18. OECD. 2010. Tourism Trends and Policies 2010, Paris: Organization for Economic Development \& Cooperation Publishing.

19. Petrevska, B. 2012. "Tourism in Macedonia - Before and After the Crisis", Conference Proceedings, International Conference "Faces of the Crisis", Skopje, Macedonia, pp:63-70.

20. Ritchie, B. W. 2004. "Chaos, Crises and Disasters: A Strategic Approach to Crisis Management in the Tourism Industry". Tourism Management 25(6). pp: 669-683.

21. Stănciulescu, G. and Micu, I.G. 2009. "The Development in Dynamics and Structure of the Romanian Tourism in the Context of the Global Crisis". Journal Of Tourism - Studies and Research in Tourism, No.7, Suceava University Press, pp: 20-25.

22. Stiglitz , J. E. 2003. "Globalization and its Discontents". W.W. Norton \& Company: London.

23. The World Bank.World Development Indicators.2014.

24. Travel \& Tourism Economic Impact 2015, Albania

25. Tribe, J. 2011. "The Economics of Recreation, Leisure and Tourism". 4th edn. Butterworth Heinemann: Oxford.

26. Tushaj, A., Thano, R. 2014. "Vlerësimi i impaktit të industrisë së turizmit në rritjen ekonomike: Rasti i Shqipërisë”. Komferenca e parë Kombëtare për Financën: Udhëkryqet e Ekonomisë Shqiptare. Departamenti i Financës. Fakulteti i Ekonomisë. Universiteti i Tiranës. 2014.

27. UNWTO. www.unwto.org. World Tourism Organization. 